\title{
Phylogenetic relationships of mid-oceanic ridge and continental lineages of Lasaea spp. (Mollusca: Bivalvia) in the northeastern Atlantic
}

\author{
Diarmaid Ó Foighil ${ }^{1, *}$, Robert Jennings ${ }^{1, * *}$, Joong-Ki Park $^{1}$, \\ D. Andrew Merriwether ${ }^{2}$
}

${ }^{1}$ Museum of Zoology and Department of Biology, University of Michigan, Ann Arbor, Michigan 48109-1079, USA

${ }^{2}$ Departments of Anthropology and Biology, University of Michigan, Ann Arbor, Michigan 48109-1382, USA

\begin{abstract}
Direct-developing lineages of the genus Lasaea are common constituents of both oceanic island and continental rocky shore crevice faunas in the eastern North Atlantic. We utilized mitochondrial gene sequence variation to flesh out the phylogenetic relationships of individuals sampled from 2 Macaronesian archipelagos (Azores, Madeira) and from downstream continental (Iberian) sites. There was no evidence for colonization of the islands by upstream western North Atlantic congeners. Of 5 Lasaea clades detected in Iberia, 1 was also present on Madeira, whereas 4 of the 5 had representatives on the Azores. Madeira did not share haplotypes with the other sampling locations. In contrast, the Azorean and Iberian samples shared multiple haplotypes and our phylogenetic tree topologies were consistent with a minimum of 6 inferred migration events across the $>1400 \mathrm{~km}$ oceanic expanse separating these 2 regional populations. Three of the putative migration events involved a predominantly island clade whose topology was consistent with colonization by ancestral continental lineages, extensive island cladogenesis, and secondary downstream migrations back to the mainland. The remaining 3 inferred migration events were distributed across the tips of the phylogenetic trees, a topology consistent with evolutionarily recent migrations against the prevailing current fields. Our results indicate that the pattern of easterly surface flow in the study area may generate differentially effective dispersal filters downstream of the Azorean and Madeiran archipelagos. Evidence for countercurrent migration in marine populations should be assessed in light of the totality of surface-flow patterns in the study system, not merely the prevailing one.
\end{abstract}

KEY WORDS: Biogeography $\cdot 16 \mathrm{~S}$ rDNA $\cdot$ Azores $\cdot$ Madeira $\cdot$ Oceanic island

Resale or republication not permitted without written consent of the publisher

\section{INTRODUCTION}

Understanding spatiotemporal patterns of biotic diversity represents one of the central challenges facing ecologists and systematists (Cracraft 1994). In the marine environment, this goal is complicated by the prevalence of sibling species among benthic invertebrates (Knowlton 1993, Klautau et al. 1999), by the

\footnotetext{
*E-mail: diarmaid@umich.edu

${ }^{* *}$ Present address: Woods Hole Oceanographic Institution, Woods Hole, Massachusetts 02543, USA
}

latent potential for long-distance dispersal events (Palumbi 1992, Carlton \& Geller 1993, Lessios et al. 1998, Ó Foighil et al. 1999), and by the enormous geographic distributions attained by many taxa (Kohn \& Perron 1994, Benzie 1999). Phylogenetic analyses of comparative molecular datasets can address these issues by helping to resolve marine sibling species complexes (Muricy et al. 1996, Ó Foighil et al. 1996, Davidson \& Haygood 1999) and by placing the genetic structuring of marine taxa into an historical context (Avise 1994, Cunningham \& Collins 1994).

Important novel phylogeographic insights have been gained from recent molecular studies of diverse marine 
invertebrates (Palumbi 1996, 1997, Chase et al. 1998, Hellberg 1998, Benzie 1999), although the emerging picture is complex. Some taxa show a genetic structure consistent with high dispersal rates among geographically distant populations, e.g., Atlantic Eucidaris spp. echinoids (Lessios et al. 1999). Others exhibit heterogeneous patterns in which previously unsuspected genetic discontinuities are apparent (Avise 1994, Lavery et al. 1996, Chase et al. 1998, Gopurenko et al. 1999) and inferred that patterns of gene flow may be inconsistent with present day patterns of oceanic circulation (Palumbi et al. 1997, Benzie 1999, Lessios et al. 1999, Ó Foighil \& Jozefowicz 1999). In this study, we utilize mitochondrial gene sequence variation to flesh out the phylogenetic relationships of oceanic island and continental direct-developing lineages of the intertidal clams Lasaea spp. in the northeastern Atlantic.

The Azorean archipelago comprises 9 major oceanic islands of volcanic origin (estimated geological ages range from 0.3 million years before present (myr bp) for Pico [Chovellon 1982] to 5.27-8.12 myr bp for Santa Maria [Féraud et al. 1984, Abdel-Monem et al. 1975 respectively]), extending $615 \mathrm{~km}$ from west to east across the mid-Atlantic Ridge (approximately 37 to $40^{\circ} \mathrm{N}, 25$ to $31^{\circ} \mathrm{W}$ ). It is situated 1800 and $1584 \mathrm{~km}$ distant from the respective nearest points on the continental margins of North America (Newfoundland) and Europe (Portugal) and $860 \mathrm{~km}$ from the nearest subaerial habitat, the Madeiran group of oceanic islands

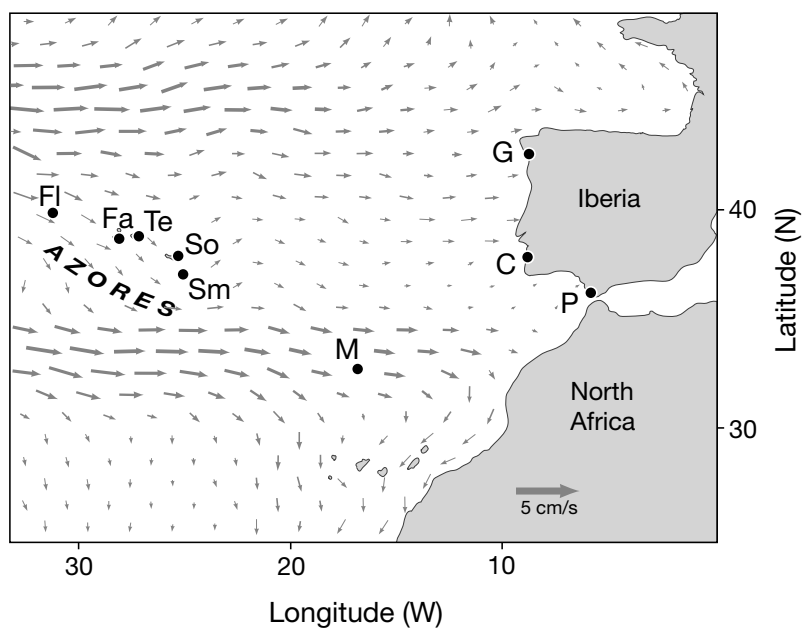

Fig. 1. Northeast Atlantic showing Azorean (Fl: Flores; Fa: Faial; Te: Terceira; So: São Miguel; Sm: Santa Maria), Madeiran (M) and Iberian (G: Galicia; C: Cabo de Sines; P: Las Palomas) sampling sites. Arrows: surface distribution of the annual mean thermal wind field, referenced to 2000 dbar (modified from Alves \& de Verdière 1999). Note that 2 zones of pronounced easterly flow bracket the Azores: the Azores Current to the south, and the North Atlantic Current to the north, of the archipelago
(Borges \& Brown 1999). Oceanic islands have never been connected to continental landmasses (Nunn 1994) and receive their biotas solely through dispersal from geographically distant source populations and from subsequent in situ diversification (Paulay 1994). The Azorean biota contains a significant number of endemic species; however, the marine fauna has explicit phylogenetic ties to the European/North African mainlands and to the other northeastern Atlantic (Macaronesian) islands (Miller 1984, Prud'homme van Reine 1988, Gofas 1990, Gosliner 1990, Moss 1992, Wirtz \& Martins 1993, Lee \& Vacquier 1995, FranciscoOrtega et al. 1996, de Wolf et al. 1998a,b, 2000, KrappSchickel \& Vader 1998, Morton et al. 1998, Salas \& Gofas 1998, Borges \& Brown 1999, Bernardi et al. 2000). This is somewhat surprising because, based on predominant present day surface circulation patterns, the archipelago is upstream from eastern putative source populations. The Azores are bracketed by 2 eastward flowing branches of the North Atlantic Gulf Stream System: the North Atlantic Current to the north (44 to $54^{\circ} \mathrm{N}$ ) of the archipelago and the Azores Current (a subtropical jet flowing eastward at 30 to $35^{\circ} \mathrm{N}$; Alves $\&$ de Verdière 1999) to the south (see Fig. 1). A net eastward surface circulation passes through the archipelago; however, local current fields are dominated by mesoscale meanders and eddies rather than a fast steady flow (Krauss \& Meincke 1982, Richardson 1985, Krauss 1986, Santos et al. 1995, Alves \& de Verdière 1999).

Atlantic populations of the genus Lasaea lack pelagic larval development (Ó Foighil 1989), and northeastern Atlantic continental populations are composed of sympatric clones (Crisp \& Standen 1988, Tyler-Walters \& Crisp 1989) that represent highly divergent phylogenetic lineages (Ó Foighil \& Smith 1995, Ó Foighil \& Jozefowicz 1999). Lasaea are 'extremely abundant' in Azorean rocky shore coralline algal tufts (Bullock et al. 1990) and are also common constituents of the intertidal crevice fauna of the European mainland. Ó Foighil \& Jozefowicz (1999) recently tested colonization hypotheses for North Atlantic oceanic island Lasaea populations by constructing molecular phylogenetic gene trees incorporating 2 continental putative source populations (Florida; Galicia, Spain) and 2 oceanic island populations (Bermuda; São Miguel, Azores). No amphiAtlantic genotypes were detected. Two phylogenetically distinct Lasaea lineages were present on São Miguel, which nested within a regional northeastern Atlantic clade but exhibited divergent levels of genetic distinctiveness from mainland sister taxa. This result is consistent with a minimum of 2, temporally distinct, inferred colonization events of São Miguel by direct-developing eastern Atlantic continental ancestors across $>1400 \mathrm{~km}$ of open ocean and against the prevailing 
present day surface circulatory patterns in the eastern North Atlantic (Ó Foighil \& Jozefowicz 1999).

Ó Foighil \& Jozefowicz's (1999) limited sampling of genetically diverse eastern Atlantic Lasaea spp. lineages did not permit a detailed reconstruction of the frequency and tempo of gene flow among Azorean and Iberian populations. Our present study aims to flesh out the genetic inter-relationships of Mid-Atlantic Ridge and continental Lasaea populations by incorporating homologous molecular data from 7 additional populations, 4 on the Azorean archipelago, 1 from the Madeiran archipelago and 2 from Iberia. Specifically, we aimed to comprehensively test the preliminary finding that Azorean Lasaea lineages are exclusively of eastern North Atlantic continental origin (Ó Foighil \& Jozefowicz 1999), to infer the minimum number and polarity of transoceanic migration events among the study populations.

\section{MATERIALS AND METHODS}

This study incorporates specimens of direct-developing Lasaea spp. sampled from rocky shore mid-zone intertidal crevices at 9 North Atlantic study locations (Fig. 1). Samples from 2 of these sites (Aguiño, Ria de Arousa, Galicia, Spain; Vila Franca do Campo, São Miguel, Azores) were collected by T. Backeljau in 1995 and were genetically characterized in an earlier North Atlantic Lasaea phylogeographic study (Ó Foighil \& Jozefowicz 1999). Additional collections were taken by the corresponding author in August 1997 from coralline algal mats at 4 Azorean (Flores, Santa Cruz das Flores; Faial, Horta; Terceira, Praia da Vitória; Santa Maria, Vila do Porto) and 2 Iberian (Cabo de Sines, Portugal; Las Palomas, Spain) locations, and in February 1999 from a single Madeiran location (Ponta de San Lourenço).

Specimens were taken from a number of microsites on each shore and pooled, prior to preservation in $95 \%$ ethanol, in order to obtain a locally representative sample of genetic diversity. From each of the 9 study populations, 30 individuals were genetically characterized by amplifying and directly sequencing a fragment (462 nucleotides, nt) of the mitochondrial large ribosomal subunit (16S) gene. A subsample of representative 16S genotypes were additionally sequenced for a $624 \mathrm{nt}$ fragment of another mitochondrial (mt) gene, cytochrome oxidase III (CO III), in order to place the North Atlantic lineages into a global phylogenetic framework (Ó Foighil \& Smith 1995). Details of the molecular techniques used for generating $16 \mathrm{~S}$ and $\mathrm{CO}$ III sequencing templates are respectively available in Ó Foighil et al. (1996) and Ó Foighil \& Smith (1995). Both strands of the target fragments were cycle- sequenced using a DNA sequencing kit (PE Applied Biosystems, Foster City, CA), and electrophoresed on an ABI 377 automated DNA sequencer. Haplotype nomenclature was based on the geographical distribution of individual mitochondrial genotypes, e.g., the PFISmSo haplotype co-occurred in the Las Palomas (P) sample in addition to the Azorean Flores (Fl), Santa Maria (Sm) and São Miguel (So) samples.

Initial alignments were performed using the CLUSTAL option of Sequence Navigator 1.0.1 (Kececioglu \& Myers 1994) and then manually adjusted to minimize mismatches. Best trees were assessed with the maximum parsimony (MP) optimality criterion (PAUP* 4.0b2a, Swofford 1998) using representatives of 3 other galeommatoidean genera (Kellia laperousi [GenBank No. AF112264], Galeomma turtoni [GenBank No. AF215772], and Chlamydoconcha orcutti [GenBank No. AF215772]), as outgroups. Analyses were performed as unweighted heuristic searches using random stepwise addition with 50 replications. Inferred sequence gaps were coded as missing characters and consensus trees were constructed using the strict consensus option in PAUP. Branch support levels were estimated using nonparametric bootstrapping (500 heuristic iterations with random stepwise addition with 10 replications) and Bremer support (decay index) values (Bremer 1994). The TreeRot program (Sorenson 1996) was used to establish a constraint statement for each node in the strict consensus tree. Support indices were calculated by subtracting the number of steps in the shortest unconstrained tree from the number of steps found in each of the constrained searches.

\section{RESULTS}

From the 7 study sites, 210 Lasaea spp. individuals were sequenced for the target $16 \mathrm{~S}$ gene fragment. Combining these novel results with those of Ó Foighil \& Jozefowicz (1999) for Azorean (São Miguel) and Iberian (Ria de Arousa, Galicia) Lasaea samples yielded a total of 270 individuals from the study area (180 Macaronesian, 90 Iberian), comprising $40 \mathrm{mt}$ 16S genotypes (Table 1). The majority of haplotypes (29 of 40) were restricted to 1 of the 9 populations sampled, including all 5 Madeiran haplotypes detected. Of the $11 \mathrm{mt}$ genotypes occurring in more than 1 site, 3 were restricted to the Azorean archipelago, 4 to the Iberian Peninsula and an additional 4 were recovered from both Azorean and mainland populations, including the most common haplotype in our dataset (PFaFlTe: 51 specimens).

MP analysis of the entire North Atlantic Lasaea 16S mt dataset (including all of Ó Foighil \& Jozefowicz's [1999] mt genotypes) revealed a major phylogenetic 
Table 1. Lasaea spp. Frequency and distribution patterns of all 40 mitochondrial $16 \mathrm{~S}$ rDNA haplotypes encountered in the 3 Iberian (G: Galicia; C: Cabo de Sines; P: Las Palomas) and 6 Macaronesian (Fl: Flores; Fa: Faial; Te: Terceira; So: São Miguel; Sm: Santa Maria; M: Madeira) samples. *Haplotype nomenclature used for 11 of the Azorean and Iberian mitochondrial genotypes in an earlier study (Ó Foighil \& Jozefowicz 1999); Gen. No.: GenBank Accession No.

\begin{tabular}{|c|c|c|c|c|c|c|c|c|c|c|c|}
\hline Haplotype & $\mathrm{C}$ & $\mathrm{G}$ & $\mathrm{P}$ & So & $\mathrm{Sn}$ & $\mathrm{Te}$ & $\mathrm{Fa}$ & $\mathrm{Fl}$ & M & Total & Gen No. \\
\hline \multicolumn{12}{|l|}{ Iberian } \\
\hline $\mathrm{GC}(\mathrm{IBd})^{*}$ & 14 & 3 & & & & & & & & 17 & AF112269 \\
\hline GP1 (IBa)* & & 3 & 6 & & & & & & & 9 & AF112270 \\
\hline GP2 (IBe) ${ }^{*}$ & & 1 & 1 & & & & & & & 2 & AF112270 \\
\hline $\mathrm{CP}$ & 4 & & 1 & & & & & & & 5 & AF215748 \\
\hline G1 $(\mathrm{IBb})^{*}$ & & 17 & & & & & & & & 17 & AF112271 \\
\hline G2 (IBc)* ${ }^{*}$ & & 4 & & & & & & & & 4 & AF112272 \\
\hline $\mathrm{C} 1$ & 5 & & & & & & & & & 5 & AF215742 \\
\hline $\mathrm{C} 2$ & 1 & & & & & & & & & 1 & AF215743 \\
\hline $\mathrm{C} 3$ & 1 & & & & & & & & & 1 & AF215744 \\
\hline $\mathrm{C} 4$ & 1 & & & & & & & & & 1 & AF215745 \\
\hline $\mathrm{C} 5$ & 1 & & & & & & & & & 1 & AF215746 \\
\hline C6 & 1 & & & & & & & & & 1 & AF215747 \\
\hline P1 & & & 3 & & & & & & & 3 & AF215749 \\
\hline P2 & & & 1 & & & & & & & 1 & AF215750 \\
\hline P3 & & & 3 & & & & & & & 3 & AF215751 \\
\hline P4 & & & 1 & & & & & & & 1 & AF215752 \\
\hline P5 & & & 1 & & & & & & & 1 & AF215753 \\
\hline $\mathrm{P} 6$ & & & 1 & & & & & & & 1 & AF215754 \\
\hline \multicolumn{12}{|l|}{ Azorean/Iberian } \\
\hline PFaFlTe & & & 7 & & & 18 & 16 & 10 & & 51 & AF215755 \\
\hline GCPFaSo $(\mathrm{AZC})^{*}$ & 2 & 2 & 3 & 3 & & & 1 & & & 11 & AF112276 \\
\hline PSm & & & 1 & & 3 & & & & & 4 & AF215756 \\
\hline PFlSmSo $(\mathrm{AZa})^{*}$ & & & 1 & 11 & 2 & & & 1 & & 15 & AF112274 \\
\hline \multicolumn{12}{|l|}{ Azorean } \\
\hline SmFaFlTe & & & & & 5 & 10 & 7 & 16 & & 38 & AF215757 \\
\hline SmSo $(\mathrm{AZd})^{*}$ & & & & 12 & 20 & & & & & 32 & AF112277 \\
\hline FaSo $(\mathrm{AZb})^{*}$ & & & & 2 & & & 1 & & & 3 & AF112275 \\
\hline Fa1 & & & & & & & 1 & & & 1 & AF215758 \\
\hline $\mathrm{Fa} 2$ & & & & & & & 1 & & & 1 & AF215759 \\
\hline $\mathrm{Fa} 3$ & & & & & & & 2 & & & 2 & AF215760 \\
\hline $\mathrm{Fa} 4$ & & & & & & & 1 & & & 1 & AF215761 \\
\hline Fl1 & & & & & & & & 2 & & 2 & AF215762 \\
\hline Fl2 & & & & & & & & 1 & & 1 & AF215763 \\
\hline So1 $(\mathrm{AZe})^{*}$ & & & & 1 & & & & & & 1 & AF112278 \\
\hline So2 (AZf) ${ }^{*}$ & & & & 1 & & & & & & 1 & AF112279 \\
\hline $\mathrm{Te} 1$ & & & & & & 1 & & & & 1 & AF215764 \\
\hline $\mathrm{Te} 2$ & & & & & & 1 & & & & 1 & AF215765 \\
\hline \multicolumn{12}{|l|}{ Madeiran } \\
\hline M1 & & & & & & & & & 15 & 15 & AF215766 \\
\hline M2 & & & & & & & & & 9 & 9 & AF215767 \\
\hline M3 & & & & & & & & & 2 & 2 & AF215768 \\
\hline M4 & & & & & & & & & 3 & 3 & AF215769 \\
\hline M5 & & & & & & & & & 1 & 1 & AF215770 \\
\hline Total: & 30 & 30 & 30 & 30 & 30 & 30 & 30 & 30 & 30 & 270 & \\
\hline
\end{tabular}

dichotomy in which each primary branch supported 3 terminal clades (Fig. 2). None of the 6 terminal clades contained haplotypes from both western (Florida/ Bermuda) and eastern (Azores/Madeira/Iberia) North Atlantic sites. The western samples formed a single shallow clade sister to an Australian indirect-developing species ( $L$. australis, sampled in Sydney, NSW: GenBank No. AF215774). The remaining 5 terminal clades were all present in the eastern continental samples, and 4 of the 5 also had representatives on the Azores. A congruent topology was obtained when exemplar mt lineages (C1, GC, FLA, PFlFmSo, GP2, SO1) from each of the 6 terminal 16S clades in Fig. 2 were additionally characterized for a $624 \mathrm{nt}$ portion of another mt gene, CO III, and added to a preexisting CO III dataset containing homologous sequences from 


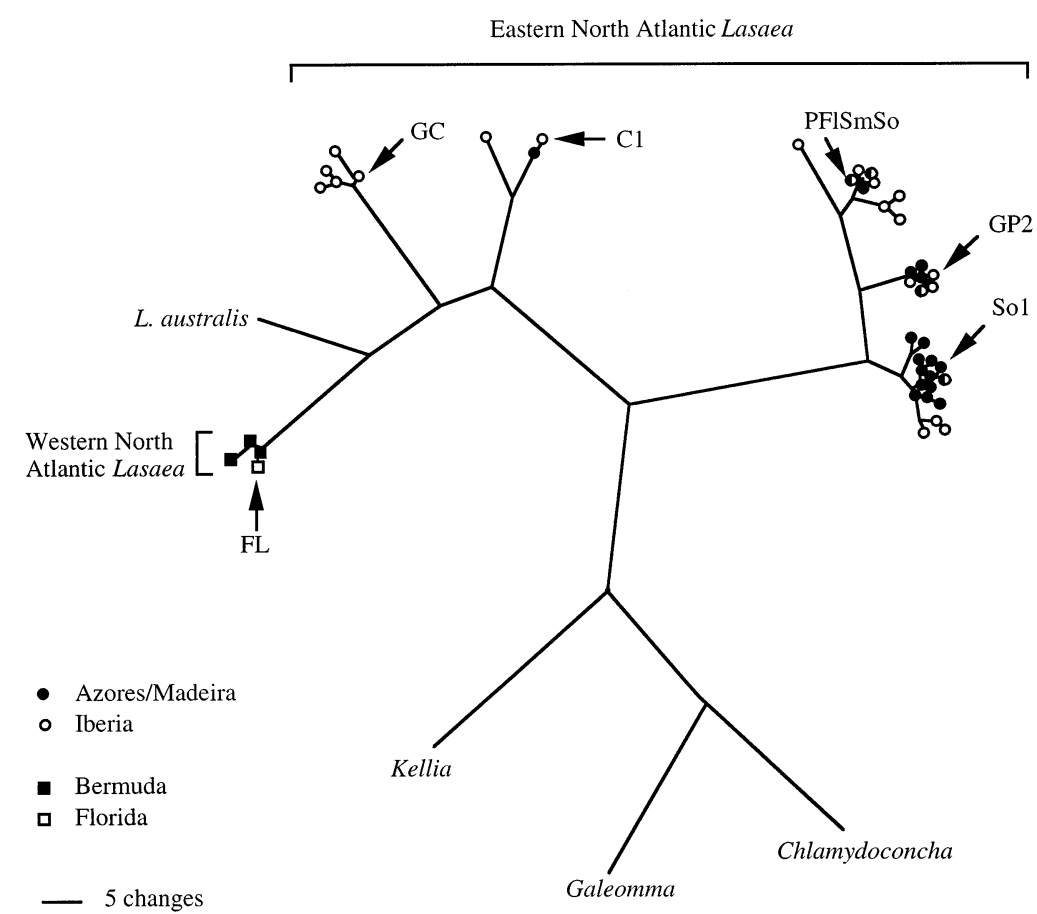
(388 steps, CI $=0.623$, Retention Index $[\mathrm{RI}]=0.892$ ) obtained with the entire North Atlantic 16S rDNA mt dataset (including all of Ó Foighil \& Jozefowicz's 1999 dataset $=$ total of 44 haplotypes representing 330 North Atlantic individuals) together with a representative haplotype of the indirect-developing Australian species L. australis. Kellia laperousi, Galeomma turtoni and Chlamydoconcha orcutti were designated outgroups, and the 5 other most parsimonious topologies differed only in minor rearrangements within the terminal clades. The positioning of an exemplar haplotype for each clade, used in global Lasaea phylogenetic analyses (Fig. 3), is indicated
Fig. 2. Lasaea spp. Unrooted phylogram of 1 of the 6 most parsimonious trees

Madeiran) and continental populations could be made. These migration inferences are premised on the assumption that specific oceanic island populations of globally distributed taxa such as Lasaea spp. (Ó Foighil 1989) do not originate de novo (Paulay 1994), but represent descendants of colonists from geographically distant source populations (eastern North Atlantic continental lineages in this case).

Of the 2 major branches in the tree topology (Fig. 4), 1 supports Terminal Clades I and II which, together, encompass 8 of $40 \mathrm{mt}$ genotypes and 33 of 270 individuals of the eastern North Atlantic dataset. The geographic distribution of Clade I and II haplotypes was highly skewed; 7 of 8 constituent haplotypes and 27 of 33 individuals were found in a single mainland site, Cabo de Sines (Fig. 4, Table 1). Indeed, only 3 of the 30 Cabo de Sines specimens clustered in Terminal Clades III, IV and V (Fig. 4, Table 1), which collectively constitute the large bulk (237 of 270 individuals) of the dataset. Clade I contained a single Macaronesian lineage (Fa3) which had 2 representatives in the Faial sample. Clade II was restricted to continental sites and, although dominated by Cabo de Sines specimens, it had representatives in all 3 mainland locations (Fig. 4, Table 1). Fa3 nested within an otherwise globally sampled congeners (Ó Foighil \& Smith 1995, Ó Foighil \& Jozefowicz 1999, Taylor \& Ó Foighil 2000). Although clearly comprised of 2 phylogenetically distinct lineages, all of the 5 exemplar eastern haplotypes were robustly, and exclusively, sisters to previously characterized (Ó Foighil \& Smith 1995) northeastern Atlantic mt genotypes from Ireland (IR) and the French Mediterranean (FEMED), including the novel 16S rDNA terminal clade represented by $\mathrm{C} 1$ (Fig. 3).

Further phylogenetic analyses were restricted to the Azorean/Madeiran and Iberian lineages, and Fig. 4 shows a strict consensus of the 16 most parsimonious trees (309 steps, CI $=0.676$, Retention Index [RI $]=$ 0.895) obtained for the eastern North Atlantic dataset. Note that the pronounced phylogenetic dichotomy and 5 eastern terminal clades evident in Fig. 2 were recovered. When the island/continental status of the 40 ingroup lineages was traced on the tree topology, a minimum of 6 inferred migration events across the oceanic expanse separating Macaronesian (Azores/ exclusively mainland section of the $16 \mathrm{~S}$ tree topology, and differed by 2 nucleotide substitutions from mainland lineage $\mathrm{C} 1$. These data are consistent with placement of an evolutionarily recent migration event, against the predominant present day current flow, on the terminal branch leading to Fa3 (Fig. 4).

The other major branch in the consensus tree topology (Fig. 4) supports Terminal Clades III, IV and V, each of which contained a mix of mainland and island haplotypes in addition to at least $1 \mathrm{mt}$ genotype occurring in both locations. Terminal Clade III was a numerically substantial component of the dataset (16 of $40 \mathrm{mt}$ genotypes; 104 of 270 individuals). Unlike the other 4 terminal eastern North Atlantic clades, it was predominantly composed of exclusively island haplotypes (12 of 16), including all 5 Madeiran lineages detected. The Madeiran samples were paraphyletic, and 2 of the Madeiran haplotypes (M2, M5) occupied a basal position within the clade. The most common Clade III haplotype, SmFaFlTe $(n=38)$, was restricted to the Azores and was present in 4 of the 5 Azorean sites sampled. 


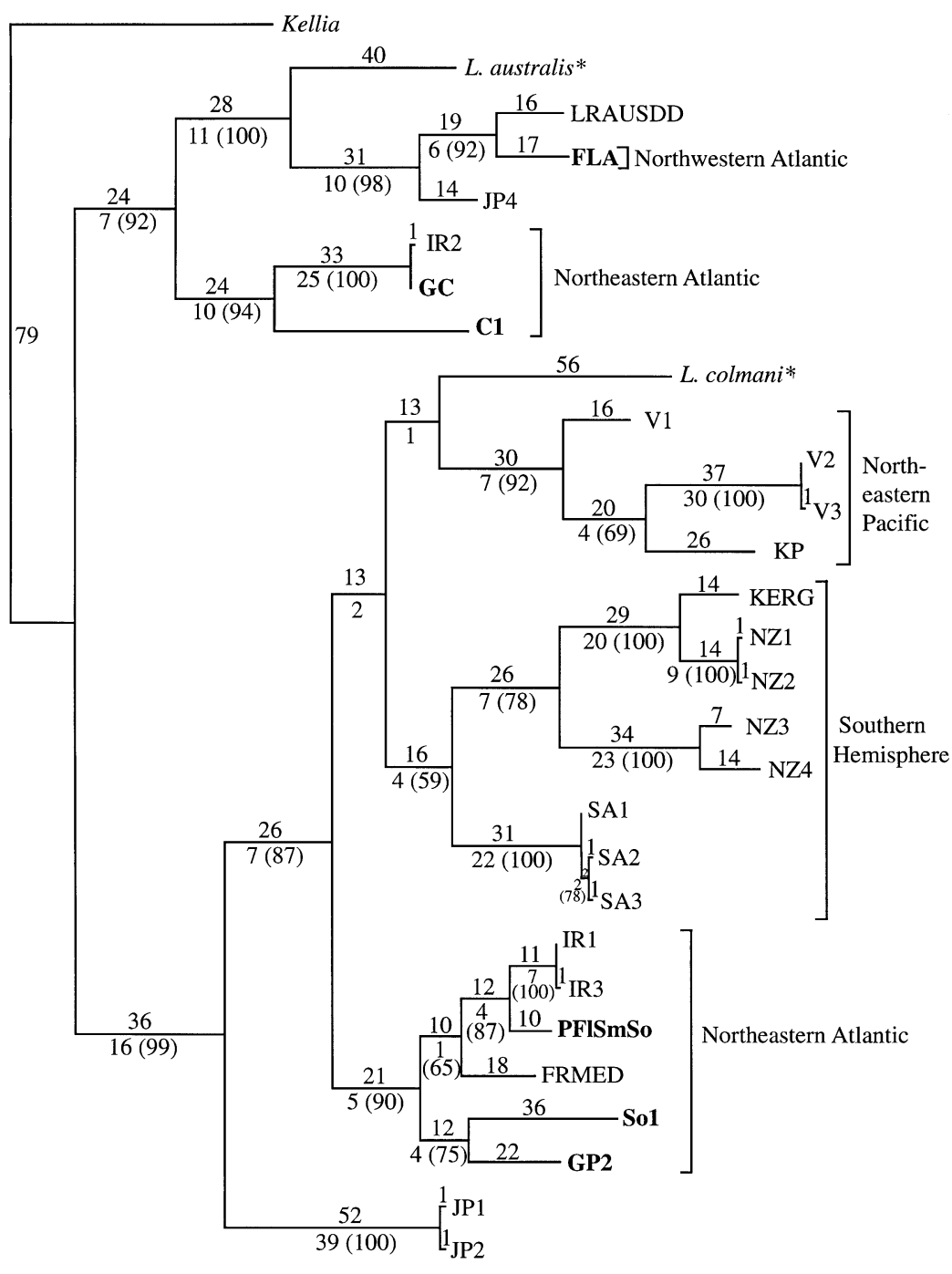

Fig. 3. Lasaea spp. The most parsimonious tree (1045 steps, CI $=0.444, \mathrm{RI}=$ 0.675 ) obtained by a heuristic search for optimal trees (PAUP) using mt CO III partial sequences (624 nt) from North Atlantic exemplar lineages of all 6 terminal clades in Fig. 2 (C1, GC, FLA, PFIFmSo, GP2, SO1), together with a homologous dataset from previously studied global Lasaea populations (Ó Foighil \& Smith 1995, Taylor \& Ó Foighil 2000). Kellia laperousi was employed as an outgroup; *: the 2 known sexual diploid Australian species, $L$. australis and L. colmani. Sampling origins of previously studied clonal, polyploid, direct-developing lineages are as follows: LRAUSDD, Australia; JP, Japan; IR, Ireland; FRMED, French Mediterranean; KERG, Kerguelen Island, southern Indian Ocean; NZ, New Zealand; SA, South Africa; V1-3 and KP, British Columbia, Canada. The respective numbers of steps are indicated above each branch and the decay index and bootstrap values supporting each node are respectively presented below the branches

stitutions (C2/SmFaFlTe) from Clade III island haplotypes. The topology of Clade III is consistent with placement of a single inferred colonization event of the islands by ancestral eastern continental lineages along the Clade III stem branch, followed by inter-archipelago exchange and cladogenesis of island lineages and by 2 separate secondary downstream migrations back to the eastern continental margin habitats (Fig. 4).

Terminal Clade IV contained approximately $20 \%$ (8 of $40 \mathrm{mt}$ genotypes and 47 of 270 individuals) of the eastern North Atlantic dataset. Of the 8 constituent haplotypes, 5 occurred exclusively in continental samples, including the most divergent lineage $(\mathrm{P} 2, \geq 16$ steps from other clade members). A single haplotype (FaSo, $\mathrm{n}=3$ ) was exclusively Azorean, and differed by 1 step from the least divergent haplotype present on the mainland (PFlSmSo). However, the majority of individual clams (26 of 47) in Clade IV represent $2 \mathrm{mt}$ genotypes (GCPFaSo; PFISmSo) that co-occur in both Azorean and continental locations. Clade IV lineages formed a basal polytomy incorporating 3 branches, 1 of which supported all of the mt genotypes present in the Azores (Fig. 4). We interpret this topological and genetic diversity data to indicate a minimum of 1 , evolutionarily recent, countercurrent migration event along the branch supporting the mt genotypes present on the Azores (Fig. 4).

The most common haplotype in the dataset, PFaFlTe, accounted for the large majority of individual clams (51 of 75) in Terminal Clade V, and occurred in both Azorean and mainland samples. The remaining Clade V haplotypes consisted of exclusively island (4) and exclusively mainland (3) lineages. Clade V was robustly monophyletic (decay index $=5$ ) however, the 8 constituent haplotypes differed by $\leq 4$ substitutions and there was very little intraclade phylogenetic structure (Fig. 4). Clade V lineages have

Mainland haplotypes were nested in 2 derived positions within Clade III. A single haplotype (PSm) was present in both Azorean (Santa Maria) and continental (Las Palomas) samples. In another section of the Clade III topology, 3 mainland haplotypes (C2, P1 and P6) co-clustered and differed by a minimum of 4 sub- apparently engaged in at least 1 evolutionarily recent migration between Mid-Atlantic Ridge and continental populations. Although the basal polytomy in the rooted analysis (Fig. 4) obscured the polarity of this event, the default polarity is a mainland to oceanic island migration (Paulay 1994). Coalescence analyses can provide 
Fig. 4. Lasaea spp. Strict consensus of the 16 most parsimonious trees (309 steps, $\mathrm{CI}=0.676, \mathrm{RI}=0.895$ ) obtained by a heuristic search for optimal trees of the mt 16S rDNA dataset (Fig. 2), utilizing Kellia laperousi, Galeomma turtoni and Chlamydoconcha orcutti as outgroups. Prefixes indicate the location(s) from which a mitochondrial genotype was obtained (see Fig. 1) and brackets after haplotype labels indicate the number of individuals detected per $\mathrm{mt}$ lineage. Bold $\mathrm{mt}$ genotype label: oceanic island haplotypes; *: mitochondrial lineages present in both oceanic island and mainland samples (their island locations are indicated by the bold component of their composite haplotype label). The 5 clades in this tree topology, referred to in the text, are indicated by the terminal brackets and identified by roman numerals. A minimum of 6 inferred migration events between Azorean and Iberian sites by direct-developing Lasaea lineages are indicated $(\mathbf{X})$ on the tree topology. Decay index and bootstrap values (if $>50$ ) supporting each node are respectively presented above and below the branches

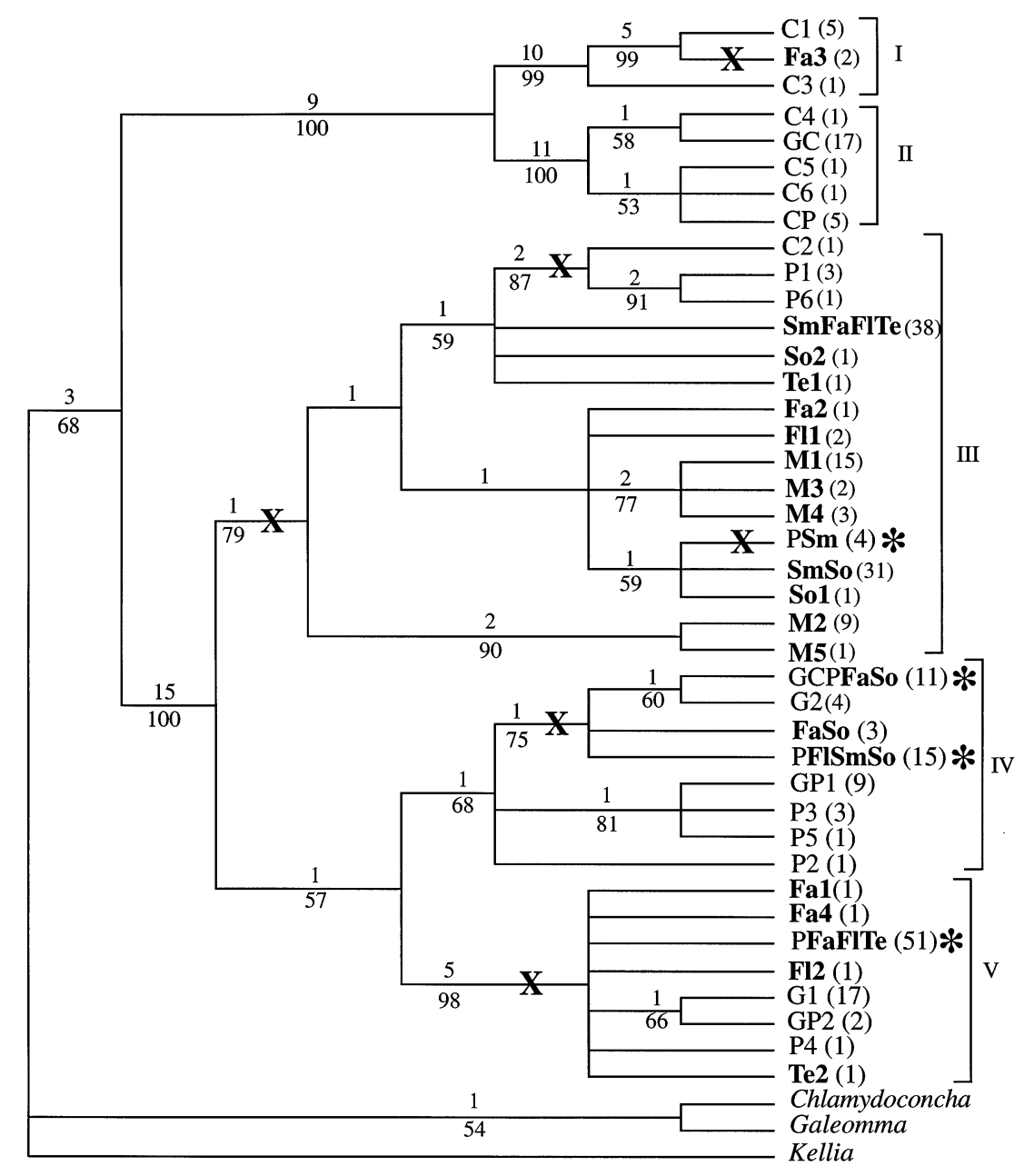

additional insights into the phylogenetic structure of closely related lineages (Donnelly \& Tavaré 1986), and an unrooted parsimony analysis of Clade $\mathrm{V}$ was also performed. The resulting tree (Fig. 5) had a starlike topology in which there was a distinct lack of networking; 5 of the 8 haplotypes had only a single connection, and a central topological position was occupied by the dominant haplotype PFaFlTe. According to coalescent theory, the probability that a given haplotype is the oldest in a population is a function of its frequency and the centrality of its positioning in topological networks (Crandall \& Templeton 1993, 1996, Beckenbach 1994). Haplotype PFaFlTe met these criteria best in Terminal Clade $\mathrm{V}$, and received the highest heuristic outgroup weighting (Fig. 5) (Castelloe \& Templeton 1994). However, because PFaFlTe occurs in both continental and island sites, it cannot be utilized to assign directionality to the inferred migration event(s). We therefore retain the default Iberia to Azores polarity (Paulay 1994) for Clade $\mathrm{V}$ transoceanic range extension among the study sites.

\section{DISCUSSION}

Our novel findings substantially refine and extend the preliminary phylogenetic conclusions reached by Ó Foighil \& Jozefowicz (1999) for Azorean/Iberian lineages of thr genus Lasaea. They robustly corroborate 1 of the primary findings of the earlier study: Azorean Lasaea samples co-clustered exclusively with eastern North Atlantic congeners and there was no evidence for transoceanic colonization by upstream western North Atlantic source-populations. According to Ó Foighil \& Jozefowicz, the absence of sister western North Atlantic/Azorean Lasaea lineages implies that either the distances involved ( $>4000 \mathrm{~km}$ ) are too great for the successful transport of intact rafting platforms from upstream source populations, or else that unfavorable Azorean environmental conditions have prevented establishment of rare upstream colonists. The Madeiran sample represents a potential control population for distinguishing among these 2 proposed limiting factors because, unlike the Azores, Madeira shares 


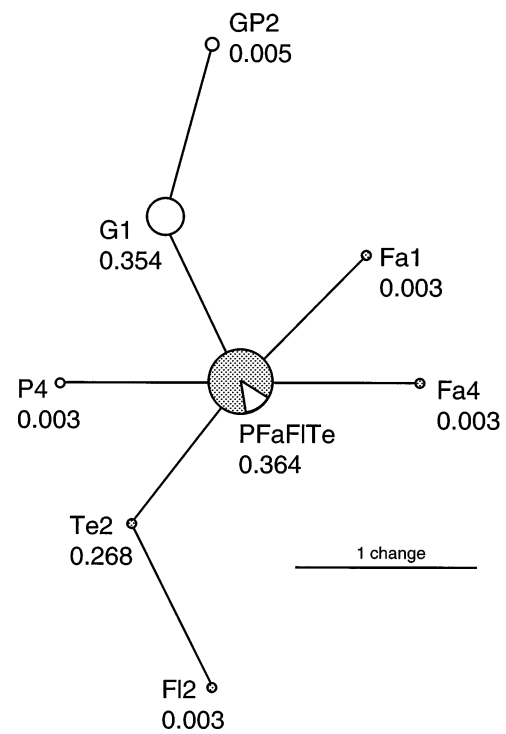

Fig. 5. Lasaea spp. Unrooted cladogram of the $816 \mathrm{~S}$ haplotypes in Clade V (Fig. 4). Diameter of the spherical symbol associated with each haplotype is proportional to its relative frequency (Table 1), and the numerical values give the outgroup weighting estimate (Castelloe \& Templeton 1994) for each haplotype. Shaded and unshaded circles, or portions thereof, indicate presences in Azorean and Iberian samples respectively. Note that the most common haplotype, PFaFlTe, which co-occurs on both the Azores and the Iberian mainland, has attained a central positioning and displays the highest outgroup weighting and the greatest degree of connectedness a result consistent with it being the oldest haplotype in the cladogram

many prominent shallow water faunal constituents with the Caribbean (Saldanha et al. 1986, Wirtz et al. 1988, Shipp 1990, Wirtz \& Martins 1993, Wirtz 1998). Nevertheless, our results reveal that Madeiran Lasaea lineages have unambiguous phylogenetic ties to Azorean and eastern North Atlantic continental congeners, indicating that the breadth of the North Atlantic separating Madeira from upstream source populations represents an effective dispersal filter for Caribbean lineages of Lasaea.

The more comprehensive sampling of regional Lasaea populations in the present study yielded a much fuller understanding of the complex phylogenetic ties connecting Macaronesian and Iberian lineages and allowed a comparative evaluation of gene flow estimates among the study populations. Tripling the sampling intensity of Iberian populations uncovered 1 novel regional clade (the relatively rare Clade I, Fig. 4) and also mainland lineages of Clade III, the predominantly Macaronesian clade which Ó Foighil \& Jozefowicz (1999) had speculated might be endemic to the Azores. Expanding the Azorean sampling effort 5 -fold increased the number of known Azorean haplotypes from 6 to 22, revealed the presence of 4 of the 5 regional eastern North Atlantic Lasaea clades on the archipelago, and raised the inferred number of transoceanic Iberian/Azorean migration events from 2 to 6 .

Of the minimum of 6 inferred migration events across the $>1500 \mathrm{~km}$ of open ocean separating the Azores from Iberia, 2 were placed towards the tips of the predominantly Macaronesian Clade III (Fig. 4) and are consistent with downstream colonization of continental habitats. These are of interest because they imply that the proximal cause of the well-documented affinities of Azorean and Iberian marine biotas (Wirtz \& Martins 1993) may not always be mainland to island colonization. A third, earlier, migration event is postulated on the stem branch of Clade III, and represents an inferred colonization of the Macaronesian islands by ancestral eastern continental lineages against the predominant flow of present day regional surface currents (Krauss \& Meincke 1982, Pollard \& Pu 1985, Richardson 1985, Santos et al. 1995, Alves \& de Verdière 1999). Based on available molluscan molecular clock estimates, Ó Foighil \& Jozefowicz (1999) speculated that this earlier migration may date from the late Pliocene, soon after the first appearance of the Azores. Absence of basal continental Clade III haplotypes in the expanded dataset is congruent with this hypothesis of 'early' Macaronesian colonization by ancestral Clade III lineages. The Madeiran haplotypes M2, M5 occupy the basal position in Clade III (Fig. 4), indicating that Clade III ancestral lineages may have colonized Madeira and the Azores in a stepping-stone fashion. Interestingly, Madeiran haplotypes were exclusively nested within the Clade III topology, and evidence for phylogenetic exchange between the 2 archipelagos is restricted to this clade.

The remaining 3 inferred continental/Macaronesian migration events are distributed across the tips of the consensus tree topology in Clades I, IV, and V (Fig. 4), involve Iberian/Azorean haplotypes which exhibit modest to zero genetic divergence values, and are consistent with evolutionarily recent genetic exchange. A countercurrent polarity has been assigned to all 3 inferred migrations. However, this interpretation is tenuous for Clade $\mathrm{V}$, in which the presumed ancestral haplotype has a joint continental/Azorean distribution (Fig. 5), and no basal lineages intersect the robust stem branch leading to the Terminal Clade $\mathrm{V}$ polytomy (Fig. 4). Our Clade V dispersal polarity assignment would be falsified if further genetic characterization uncovered basal lineages in the Azores, but would be corroborated by the discovery of such in continental populations.

The inferred countercurrent dispersal events in Clades I, IV, and V are inherently enigmatic because they involve the Azores, but apparently not Madeira (based on the available data), and because gene tree 
topologies alone often cannot distinguish among potential dispersal modes (Palumbi 1997), e.g., human introduction and/or spontaneous rafting events. Ó Foighil \& Jozefowicz (1999) entertained a potential role for anthropogenic introduction to account for the presence of Clade IV haplotype GCPFaSo in their São Miguel (eastern Azorean island group) and Galician samples. Subsequent discovery of this haplotype also in Faial (middle Azorean island group) makes its historical introduction to the Azores by humans less likely, because of the low probability of 2 independent introductions, or of extensive inter-island spread of these direct-developers, within the past half-millennium (Duncan 1972). Human-mediated introduction is least plausible for other mt genotypes, such as PFaFlTe (the most common haplotype in the dataset) and PFISmSo, which were recovered from 1 mainland site (Los Palomas) and from a variety of Azorean islands spanning the extremities of the archipelago (Fig. 1, Table 1). Furthermore, it is not clear why anthropogenic introduction might be pervasive in the Azores but undetectable in Madeira. Our novel results indicate that the pattern of prevailing easterly surface flow in the study area may generate differentially effective dispersal filters downstream of the Azorean and Madeiran archipelagos.

How might rafted Iberian Lasaea propagules reach the Azores against the prevailing surface flow? Recent detailed studies of circulation patterns in the Azores Front Current System have revealed it to be a region of complex and dynamic mesoscale circulation (Santos et al. 1995, Cromwell et al. 1996, Fernandez \& Pingree 1996, Alves \& de Verdière 1999, Pingree et al. 1999). The Azores Current (AzC) proper is a permanent shallow, almost zonal, subtropical jet which transports an estimated $13 \mathrm{~Sv}\left(\mathrm{~Sv}=10^{6} \mathrm{~m}^{3} \mathrm{~s}^{-1}\right)$ (Alves \& de Verdière 1999). Associated with this jet, and just north of it, is the smaller $(2 \mathrm{~Sv})$ westward-flowing and eddy-driven subsurface Azores Countercurrent (AzCC, not evident in Fig. 1) with maximum intensity between 200 and $500 \mathrm{~m}$ depth (Alves \& de Verdière 1999). Significantly, elements of the westward flow may also extend, at least temporarily, to surface waters (Santos et al. 1995, Alves \& de Verdière 1999). For instance, Cromwell et al. (1996) used altimetry and hydrographic data to detect persistent westward surface flow over a 3 mo period in late winter/early spring at $35^{\circ} \mathrm{N}, 28^{\circ} \mathrm{W}$, which they attributed to retroflection of water from the northern edge of the AzC. The AzC extends eastward to the Gulf of Cadiz (Alves \& de Verdiere 1999), and northern-edge retroflection events might act as an intermittent westward conduit for rafted Lasaea propagules entrained in this section of the Azores Front Current System. Madeira lies within the main eastward flow of the AzC (Fig. 1), and is therefore less likely to be routinely approached by eddy-generated surface westerly flow at the northern edge of this subtropical jet. At our present state of knowledge, northern $\mathrm{AzC}$ edge retroflection events represent a potential explanation for the prevalence of Lasaea haplotypes PFaFlTe ( $\mathrm{n}=51)$, PFISmSo $(\mathrm{n}=15)$ and GCPFaSo $(n=11)$ in the Las Palomas and Azorean archipelago samples.

Molecular studies of a variety of marine taxa have inferred patterns of gene flow that are inconsistent with present day oceanic circulation patterns (Palumbi et al. 1997, Benzie 1999, Lessios et al. 1999). Our Macaronesian Lasaea samples provide a striking example of such incongruence in that we find no evidence for colonization by upstream western North Atlantic lineages. Benzie (1999) referred to similar patterns of range extension by coral reef species as 'ghosts of dispersal past', implying that they are likely to have resulted from dispersal under different current patterns to those prevailing at present. Such an interpretation may be pertinent in the case of the predominantly Macaronesian Clade III, found in both Madeira and the Azores, in which the Iberian haplotypes occupy derived positions (Fig. 4). However, it does not seem to apply to Clades IV and V, which are dominated by haplotypes that co-occur in Azorean and Iberian samples (GCPFaSo, PFlSmSo, PFaFlTe, Fig. 4), a result consistent with evolutionarily recent migration against the prevailing surface current polarity. We propose that eddy-driven westward retroflection of surface water from the northern edge of the AzC may underlie this unexpected pattern. The comparative phylogenetic isolation of our Madeiran sample indicates that impingement by the northern edge of the AzC may be a more important factor in enhancing contemporary westward Lasaea gene flow than the relative geographic proximity of the individual Macaronesian island groups to continental source-populations.

It is not clear at present how specific our findings are to the taxon, and to the particular section of the North Atlantic Gyre System, we investigated. If edge retroflection of the $\mathrm{AzC}$ is an important regional mechanism of generating westward gene flow, then we predict that additional phylogeographic characterization of Macaronesian/Iberian benthic marine taxa will yield patterns congruent with our Lasaea results. In the meantime, we suggest that evidence for evolutionarily recent, countercurrent gene flow in marine populations be assessed in light of the totality of surface-flow patterns in the study system, not merely the prevailing one.

Acknowledgements. We are most grateful for the generous assistance of A. Frias-Martins in facilitating this study. J. Megahan helped prepare Figs. 1 \& 5. Our thanks to Paul Scott and Gonzalo Giribet for providing samples of the outgroups 
Chlamydoconcha orcutti and Galeomma turtoni respectively. The comments of 4 anonymous reviewers considerably improved the manuscript. Support was provided by a National Geographic Research Grant and NSF award OCE 9617689 to D.ÓF.

\section{LITERATURE CITED}

Abdel-Monem A, Fernandez LA, Boone GM (1975) K-Ar ages for the eastern Azores group (Santa Maria, São Miguel and the Formigas islands). Lithos 8:247-54

Alves MLGR, de Verdière AC (1999) Instability dynamics of a subtropical jet and applications to the Azores Front Current System: eddy-driven mean flow. J Phys Oceanogr 29: $837-864$

Avise JC (1994) Molecular markers, natural history and evolution. Chapman \& Hall, New York

Beckenbach AT (1994) Mitochondrial haplotype frequencies in oysters: neutral alternatives to selection models. In: Golding B (ed) Non-neutral evolution: theories and molecular data. Chapman \& Hall, New York, p 188-198

Benzie JAH (1999) Genetic structure of coral reef organisms: ghosts of dispersal past. Am Zool 39:131-145

Bernardi G, Robertson DR, Clifton KE, Azzurro E (2000) Molecular systematics, zoogeography and evolutionary ecology of the Atlantic parrotfish genus Sparisoma. Mol Phylogenet Evol 15:292-300

Borges PAV, Brown VK (1999) Effect of island geological age on the arthropod species richness of Azorean pastures. Biol J Linn Soc 66:373-410

Bremer K (1994) Branch support and tree stability. Cladistics 10:295-304

Bullock RC, Turner RD, Fralick RA (1990) Species richness and diversity of algal-associated micromolluscan communities from São Miguel, Açores. Açoreana 1990(Suppl): $39-58$

Carlton JT, Geller JB (1993) Ecological roulette: the global transport of non-indigenous marine organisms. Science 261:78-82

Castelloe J, Templeton AR (1994) Root probabilities for intraspecific gene trees under neutral coalescent theory. Mol Phylogenet Evol 3:102-113

Chase MR, Etter RJ, Rex MA, Quattro JM (1998) Bathymetric patterns of genetic variation in a deep-sea protobranch bivalve, Demninucula atacellana. Mar Biol 131:301-308

Chovellon P (1982) Évolution volcanotectonique des iles de Faial et de Pico, Archipel des Açores, Atlantique Nord. Thése de Docteur 3ème cycle. Université de Paris-Sud, Centre d'Orsay, Paris

Cracraft J (1994) Species diversity, biogeography and the evolution of biotas. Am Zool 34:33-47

Crandall KA, Templeton AR (1993) Empirical tests of some predictions from coalescent theory with applications to intraspecific phylogeny reconstruction. Genetics 134: 959-969

Crandall KA, Templeton AR (1996) Applications of intraspecific phylogenetics. In: Harvey PH, Leigh Brown AJ, Maynard Smith J, Nee S (eds) New uses for new phylogenies. Oxford University Press, Oxford, p 81-99

Crisp DJ, Standen A (1988) Lasaea rubra (Montagu) (Bivalvia: Erycinea), an apomictic crevice-living bivalve with clones separated by tidal level preference. J Exp Mar Biol Ecol 117:27-45

Cromwell D, Challenor PG, New AL, Pingree RD (1996) Persistent westward flow in the Azores Current as seen from altimetry and hydrography. J Geophys Res 101:11923-11933
Cunningham CW, Collins TM (1994) Developing model systems for molecular biogeography: vicariance and interchange in marine invertebrates. In: Schierwater B, Streit B, Wagner GP, DeSalle R (eds) Molecular ecology and evolution: approaches and applications. Birkhauser Verlag, Basel, p 405-433

Davidson SK, Haygood MG (1999) Indentification of sibling species of the bryozoan Bugula neritina that produce different anticancer bryostatins and harbor distinct strains of the bacterial symbiont 'Candidatus Endobugula sertula'. Biol Bull 196:273-280

de Wolf H, Backeljau T, Van Dongen S, Verhagen R (1998a) Large scale patterns of shell variation in Littorina striata, a planktonic developing periwinkle from Macaronesia (Mollusca: Prosobranchia). Mar Biol 131:309-317

de Wolf H, Backeljau T, Verhagen R (1998b) Lack of significant esterase and myoglobin differentiation in the periwinkle, Littorina striata (Gastropoda: Prosobranchia). Hydrobiologia 378:27-32

de Wolf H, Verhagen R, Backeljau T (2000) Large scale population structure and gene flow in the planktonic developing periwinkle, Littorina striata, in Macaronesia (Mollusca: Gastropoda). J Exp Mar Biol Ecol 246:69-83

Donnelly P, Tavaré S (1986) The ages of alleles and a coalescent. Adv Appl Probab 18:1-19

Duncan TB (1972) Atlantic islands, Madeira, the Azores and the Cape Verdes in seventeenth-century commerce and navigation. The University of Chicago Press, Chicago

Féraud G, Schmincke J, Lietz J, Gostaud G, Pritchard G, Bleil U (1984) New K/Ar ages, chemical analyses and magnetic data from the islands of Santa Maria (Azores), Porto Santo and Madeira Archipelago) and Gran Canaria (Canary Islands). Arquipél Cienc Nat 5:213-240

Fernandez E, Pingree RD (1996) Coupling between physical and biological fields in the North Atlantic subtropical front southeast of the Azores. Deep-Sea Res 43:1369

Francisco-Ortega J, Jansen RK, Santos-Guerra A (1996) Chloroplast DNA evidence of colonization, adaptive radiation, and hybridization in the evolution of the Macaronesian flora. Proc Natl Acad Sci USA 93:4085-4090

Gofas S (1990) The littoral Rissoidae and Anabathridae of São Miguel, Azores. Açoreana 1990(Suppl):97-134

Gopurenko D, Hughes JM, Keenan CP (1999) Mitochondrial DNA evidence for rapid colonization of the Indo-West Pacific by the mudcrab Scylla serrata. Mar Biol 134: $227-233$

Gosliner TM (1990) Opisthobranch mollusks from the Azores Islands. I. Runcinidae and Chromodorididae. Açoreana 1990(Suppl):135-166

Hellberg ME (1998) Sympatric sea shells along the sea's shore: the geography of speciation in the marine gastropod Tegula. Evolution 52:1311-1324

Kececioglu J, Myers E (1994) Sequence navigator, 1.0.1 Perkin Elmer Applied Biosystems, Inc, Foster City, CA

Klautau M, Russo CAM, Lazoski C, Boury-Esnault N, Thorpe JP, Solé-Cava AM (1999) Does cosmopolitanism result from overconservative systematics? A case study using the marine sponge Chondrilla nucula. Evolution 53:1414-1422

Knowlton N (1993) Sibling species in the sea. Annu Rev Ecol Syst 24:189-216

Kohn AJ, Perron FE (1994) Life history and biogeography patterns in Conus. Oxford Biogeogr Ser 9, Clarendon Press, Oxford

Krapp-Schickel T, Vader W (1998) What is, and what is not, Caprella acanthifera Leach, 1814 (Amphipoda, Caprellidea)? Part 1: the acanthifera-group. J Nat Hist 32: 949-967 
Krauss W (1986) The North Atlantic current. J Geophys Res 91:5061-5074

Krauss W, Meincke J (1982) Drifting buoy trajectories in the North Atlantic Current. Nature 295:737-740

Lavery S, Moritz C, Fielder DR (1996) Genetic patterns suggest exponential population growth in a declining species. Mol Biol Evol 13:1106-1113

Lee YH, Vacquier VD (1995) Evolution and systematics in Haliotidae (Mollusca: Gastropoda): inferences from DNA sequences of sperm lysin. Mar Biol 124:267-278

Lessios HA, Kessing BD, Robertson DR (1998) Massive gene flow across the world's most potent marine biogeographic barrier. Proc R Soc Lond Ser B Biol Sci 265:583-588

Lessios HA, Kessing BD, Robertson DR, Paulay G (1999) Phylogeography of the pantropical sea urchin Eucidaris in relation to land barriers and ocean currents. Evolution 53: 806-817

Miller PJ (1984) The gobiid fishes of temperate Macaronesia (eastern Atlantic). J Zool 204:363-412

Morton B, Britton JC, Frias Martins AM (1998) Coastal ecology of the Açores. Sociedade Alfonso Chaves, Ponta Delgada

Moss D (1992) A summary of the Porifera collected during 'Expedition Azores 1989'. Arquipél Bull Univ Azores Life Mar Sci 10:45-53

Muricy G, Solé-Cava AM, Thorpe JP, Boury-Esnault N (1996) Genetic evidence for extensive cryptic speciation in the subtidal sponge Plankina trilopha (Porifera: Demospongiae: Homoscleromorpha) from the Western Mediterranean. Mar Ecol Prog Ser 138:181-187

Nunn P D (1994) Oceanic islands. Oxford, Blackwell

Ó Foighil D (1989) Planktotrophic larval development is associated with a restricted geographic range in Lasaea, a genus of brooding, hermaphroditic bivalves. Mar Biol 103: 349-358

Ó Foighil D, Jozefowicz CJ (1999) Amphi-Atlantic phylogeography of direct-developing lineages of Lasaea, a genus of brooding bivalves. Mar Biol 135:115-122

Ó Foighil D, Smith MJ (1995) Evolution of asexuality in the cosmopolitan marine clam Lasaea. Evolution 49:140-150

Ó Foighil D, Hilbish TJ, Showman RS (1996) Mitochondrial gene variation in Mercenaria clam sibling species reveals a relict secondary contact zone in the Western Gulf of Mexico. Mar Biol 126:675-683

Ó Foighil D, Marshall BA, Hilbish TJ, Pino MA (1999) TransPacific range extension by rafting is inferred for the flat oyster Ostrea chilensis. Biol Bull 196:122-126

Palumbi SR (1992) Speciation on a small planet. Trends Ecol Evol 7:114-118

Palumbi SR (1996) What can molecular genetics contribute to marine biogeography? An urchin's tale. J Exp Mar Biol Ecol 203:75-92

Palumbi SR (1997) Molecular biogeography of the Pacific. Coral Reefs 16:S47-S52.

Palumbi SR, Grabowsky G, Duda T, Geyer L, Tachino N (1997) Speciation and population genetic structure in tropical

Editorial responsibility: Otto Kinne (Editor),

Oldendorf/Luhe, Germany
Pacific sea urchins. Evolution 51:1506-1517

Paulay G (1994) Biodiversity on oceanic islands - its origin and extinction. Am Zool 34:134-144

Pingree RD, Garcia-Soto C, Sinha B (1999) Position and structure of the Subtropical/Azores Front region from combined Lagrangian and remote sensing (IR/altimeter/SeaWiFS) measurements. J Mar Biol Assoc UK 79:769-792

Pollard RT, Pu S (1985) Structure and circulation of the upper Atlantic Ocean northeast of the Azores. Prog Oceanogr 14: 443-462

Prud'homme van Reine WF (1988) Phytogeography of seaweeds of the Azores. Helgol Meeresunters 42:165-186

Richardson PL (1985) Drifting derelicts in the North Atlantic 1883-1902. Prog Oceanogr 14:463-483

Salas C, Gofas S (1998) Description of four new species of Neolepton Monterosato 1875 (Mollusca: Bivalvia: Neoleptonidae), with comments on the genus and on its affinity with the Veneracea. Ophelia 48:35-70

Saldahna L, Maul M, Biscoito M, Andrade F (1986) On the identity of Heteroconger longissimus Günther 1870 and Heteroconger halis (Böhlke 1957) (Pisces Congridae). Bocagiana (Funchal) 104:1-17

Santos RS, Hawkins S, Monteiro LR, Alves M, Isidro EJ (1995) Marine research, resources and conservation in the Azores. Aquat Conserv 5:311-354

Shipp RL (1990) Tetradontidae. In Quéro JC, Hureau JC, Karrer C, Post A, Saldahna L (eds) Check list of the fishes of the eastern tropical Atlantic. UNESCO, Paris, p 1069-1072

Sorenson M D (1996) TreeRot. University of Michigan, Ann Arbor, MI

Swofford DL (1998) PAUP*: phylogenetic analysis using parsimony ( ${ }^{*}$ and other methods). Version 4 . Sinauer Associates, Sunderland, MA

Taylor DJ, Ó Foighil D (2000) Transglobal comparisons of nuclear and mitochondrial genetic structure in a marine polyploid clam (Lasaea, Lasaeidae). Heredity 84:321-330

Tyler-Walters H, Crisp DJ (1989) The modes of reproduction in Lasaea rubra (Montagu) and L. australis (Lamarck): (Erycinidae; Bivalvia). In: Ryland JS, Tyler PA (eds) Proceedings of the 23rd European Marine Biological Symposium, Swansea. Olsen \& Olsen, Denmark, p 299-308

Wirtz P (1998) Twelve invertebrate and eight fish species new to the marine fauna of Madeira, and a discussion of the zoogeography of the area. Helgol Meeresunters 52: 197-207

Wirtz P, Martins H (1993) Notes on some rare and little known marine invertebrates from the Azores - with a discussion of the zoogeography of the area. Arquipél Bull Univ Azores Life Mar Sci 11:55-63

Wirtz P, Müller B, Nahke P (1988) The Caribbean shrimp Tuleariocarus neglecta Chace, 1969 found in association with Diadema antillarum at Madiera, and two new records of decapod crustaceans from the Cape Verde islands. Cour Forschungsinst Senckenb 105:169-171

Submitted: February 24, 2000; Accepted: August 31, 2000 Proofs received from author(s): March 13, 2001 